CAPITAL AND TIME 


\section{U R R E N C IES}

\section{New Thinking for Financial Times}

Melinda Cooper and Martijn Konings, Series Editors 


\title{
Capital and Time
}

For a New Critique of Neoliberal Reason

\author{
MARTIJN KONINGS
}

Stanford University Press

Stanford, California 
Stanford University Press

Stanford, California

(C) 2018 by the Board of Trustees of the Leland Stanford Junior University.

All rights reserved.

No part of this book may be reproduced or transmitted in any form or by any means, electronic or mechanical, including photocopying and recording, or in any information storage or retrieval system without the prior written permission of Stanford University Press.

Printed in the United States of America on acid-free, archival-quality paper

Library of Congress Cataloging-in-Publication Data

Names: Konings, Martijn, I975- author.

Title: Capital and time : for a new critique of neoliberal reason / Martijn Konings.

Other titles: Currencies (Series)

Description: Stanford, California : Stanford University Press, 2018. I

Series: Currencies: new thinking for financial times I Includes bibliographical references and index.

Identifiers: LCCN 2017019565 I ISBN 978 I 503603905 (cloth : alk. paper) I ISBN 9781 503604438 (pbk. : alk. paper) I ISBN 978 I 503604445 (e-book)

Subjects: LCSH: Speculation. I Capital market. I Finance-Government policy.

I Capitalism. I Neoliberalism.

Classification: LCC HG6o 5 .K66 2018 I DDC 332/.04I-dc23

$\mathrm{LC}$ record available at https://lccn.loc.gov/201 7019565

Typeset by Classic Typography in Io/I 5 Janson 